School of Finance

University of St.Gallen

SOVEREIGN RISK AND THE PRICING OF CORPORATE CREDIT DEFAULT SWAPS

MATTHIAS HAERRI

STEFAN MORKOETTER

SIMONE WESTERFELD

WORKING PAPERS ON FINANCE No. 2014/23

SWISS INSTITUTE OF BANKING AND FINANCE (S/BF - HSG)

MAY 2014 


\title{
Sovereign Risk and the Pricing of Corporate Credit Default Swaps
}

\author{
Matthias Haerri*, Stefan Morkoetter**, and Simone Westerfeld ${ }^{* * *}$ \\ November 2014
}

\begin{abstract}
Based on an empirical analysis of European corporations, we investigate the impact of sovereign risk on the pricing of corporate credit risk. In our paper, we show that sovereign credit default swaps (CDS) are positively correlated with corresponding corporate CDS spreads and are a significant factor for corporate CDS pricing models. We also find that this impact increases throughout the sovereign debt crisis in 2010-2011 and is more distinctive for Eurozone countries that were more exposed to the sovereign debt crisis than others. We further observe that this effect is particularly pronounced for corporations with a high dependency on their domestic market.
\end{abstract}

Keywords: $\quad$ Credit Default Swaps, Pricing, Sovereign Risk

JEL Classification: G12, G14, G24

* Matthias Haerri, University of Applied Sciences Northwestern Switzerland, matthias.haerri@fhnw.ch

** Stefan Morkoetter, University of St. Gallen, stefan.morkoetter@unisg.ch

*** Simone Westerfeld: University of Applied Sciences Northwestern Switzerland, simone.westerfeld@fhnw.ch

Acknowledgements: We thank Austin Murphy, Marc Arnold, Roman Stebler, and an anonymous referee as well as conference participants of the 3rd International Conference on Credit Analysis and Risk Management (2014) at Oakland University (Rochester, MI) for useful comments. We thank Julia Blattner for assistance in preparing the data. 


\section{Introduction}

During the European sovereign crisis in 2010-2011 governments once again experienced that investors increasingly focused their attention on sovereign counterparty risk. Interest rate levels for so-called peripheral countries of the Eurozone (e.g. Spain) increased steadily, whereas more stable European economies (e.g. Germany) benefited from an opposing trend (e.g. lower borrowing costs). Against this background, we investigate to what extent the creditworthiness of a country - measured by the underlying sovereign CDS spread - spills over to the credit risk of its local companies. First empirical results actually show that indeed interest rates of new bank loans (corporate loans as well as household loans) were increasing during the financial crisis in the peripheral countries of the Eurozone, whereas the core Eurozone countries actually benefited from a decrease. Between December 2010 and July 2012 interest rates for corporate loans decreased for example in Germany on average by 55 basis points. However during the same time period interest rates for corporate loans in Italy increased by 80 basis points - adding up to an absolute delta of 1.35\% (IMF, 2012).

Set against the background of the European sovereign crisis, the main aim of our paper is to introduce sovereign risk (via sovereign CDS spreads) to the pricing model of corporate CDS contracts. We also control if the potential impact of sovereign risk is driven by operational or refinancing activities on the company level. Literature on CDS pricing has so far covered a wide range of potential pricing factors including for example company specific factors like leverage, liquidity or equity volatility (e.g. Longstaff et al., 2005; Ericsson et al., 2009, Zhang et al., 2008). Other studies focus on the relationship between stock, bond or CDS markets and the corresponding inter-linkages (e.g. Blanco et al., 2005) or on the impact of counterparty risk on CDS pricing (Morkoetter et al., 2012). Among others, Acharya et al. (2013), Alter and Schueler (2012), Demirgüç-Kunt and Huizinga (2013) and De Bruyckere et al. (2013) focus on the pricing of bank CDS and report a positive correlation between sovereign CDS and bank CDS levels.

Throughout the empirical part of our paper, we argue that an increase in sovereign CDS spreads is positively correlated with the CDS spreads of corporates headquartered in the same country. Our argument is as follows: Due to a weak economic outlook, the creditworthiness of a government might be decreasing, which in turn is accompanied by higher sovereign CDS spread levels. From the perspective of corporates headquartered in a country with a lower creditworthiness, the operational business activities might be negatively affected (e.g. lower 
sales in their domestic market due to a weak economy). In contrast, companies domiciled in a country with a sound credit rating and therefore having a strong economy should in turn benefit from such a stable environment. If our argument holds, we expect that a strong home bias towards the local market should have - depending on the underlying sovereign risk - a negative (bad underlying sovereign risk) or positive (sound underlying sovereign risk) effect on the observed corporate risk levels.

A good timeframe and geographical region to study the pricing power of sovereign CDS spreads on corporate risk levels is the Eurozone throughout the recent sovereign debt crisis: High levels of volatility were observed for sovereign CDS spreads, combined with a diverging pattern between the different countries (depending on the creditworthiness of the individual country). In our empirical analysis we focus on CDS Spreads of 107 European corporates from 10 different countries for the time period January 2009 until December 2011. Controlling for a range of different control variables (e.g. leverage), we regress the sovereign CDS spreads (according to the location of the company's headquarter) on the individual corporate CDS spread. In addition, we also collected the respective company-specific variables with regard to the ratio of domestic market sales and bank debt over total debt from the respective annual reports.

We present three main results: First, our results indicate that sovereign CDS spreads are indeed significantly linked to the underlying corporate CDS spread. Second, we observe that the impact of sovereign credit risk is actually increasing with an intensifying sovereign crisis in 2010 and 2011. Third, for corporations headquartered in one of the distressed Eurozone countries (e.g. Spain), the underlying link between domestic sovereign risk and corporate CDS spreads is significantly stronger as compared to corporates domiciled in a non-distressed Eurozone country (e.g. Germany). We interpret the results as empirical proof that sovereign risk matters and that it has a direct impact on corporate credit risk.

In a second step, our paper focuses on the reasoning behind the documented impact of sovereign risk on the pricing of the underlying corporate CDS spreads. Is this linkage actually reasonable from a corporate perspective? Does it make sense that an Italian manufacturer ultimately has to pay higher interest rates in contrast to his German peer producing the very same products? Following this argument, we first control for domestic market activity. For most companies, the domestic market (where the company HQ is located) is a very important one. Against this background we argue that the impact of sovereign risk on corporate credit risk 
levels is justified. Thus, a negative outlook for the domestic economy is ultimately linked to decreasing sales, which in turn will trigger a lower level of profitability and a lower creditworthiness of the corporations. Second, on the refinancing side, companies may also be impacted by the conditions of the corresponding sovereign risk. During the European sovereign debt crisis, banks in distressed countries experienced difficulties to refinance themselves. This shortage of capital supply drove up the banks refinancing costs. Under the assumption that borrowing from banks is predominately a domestic business, we could argue that a higher dependency on (local) bank debt should also lead to a higher impact of sovereign counterparty risk on corporate CDS spreads. Application of interaction terms between "domestic market dependency" and "sovereign CDS spread" brings empirical proof that a higher dependency on the domestic market (measured in \% of annual sales volume) leads to a higher impact of the corresponding sovereign CDS level. However, with regard to the second hypothesis, we do not find any empirical proof that a higher ratio of bank debt (in \% of total debt) is associated with a higher weight on sovereign counterparty risk, when pricing CDS spread levels.

The remainder of the paper is organized as follows. In section 2 we briefly discuss the sovereign debt crisis in Europe, which motivates our paper. Section 3 provides an overview of the relevant literature covering both pricing factors of CDS spreads and sovereign risk in general. Section 4 presents the data and section 5 explains the methodology. Section 6 displays the empirical results. Finally, Section 7 concludes the paper.

\section{Sovereign debt crisis in Europe (2009-2011)}

Following the Lehman default in September 2008, the worldwide financial crisis hit particularly the banking sector in 2008/2009. However, from a European perspective this was only half of the story: Starting in 2009, bond yields as well as CDS spread levels of sovereign debt of selected European countries increased significantly (e.g. Hui and Chang, 2011). This group of countries is often referred to as so-called peripheral Eurozone countries and include for example Greece, Spain and Italy. The major reason for the increased risk awareness of investors and subsequently higher demanded risk premia were high debt levels, high budget deficits as well as subsequently weak national economies. The crisis evolved in early 2009 with Ireland announcing several measures to tighten the national budget followed by Greece in October 2009 stating severe fiscal problems and revealing a budget deficit of $12.7 \%$ of the GDP for 2009 shortly afterwards (see also De Santis, 2012). As a consequence, the creditwor- 
thiness of countries with less solid fiscal fundamentals came under pressure and this led to increased spread levels (please refer to Figure 1). Rating agencies reacted accordingly and downgraded the effected countries, which puts further pressure on these countries. With increasing refinancing costs and widening budget deficits it become more and more difficult for these peripheral Eurozone countries to borrow from capital markets. In 2010 Greece and Ireland had no access to the bond markets and could only refinance themselves via repeated bailouts coordinated by the European Union as well as the International Monetary Fund. Other countries followed with their case subsequently. Spain also required a limited form of external help by the European Union in order to capitalize its banking sector. Eurozone members voted to set-up a temporary European Financial Stability Facility (EFSF) which - based on guarantees of all Eurozone member states - could issue bonds in order to provide funding to member countries with refinancing difficulties. Later on, the European Stability Mechanism (ESM) was introduced as a permanent alternative to the EFSF (see for example Lane, 2012).

The difficulties these countries were facing in 2009/2010 can be related to some degree to their membership in the Eurozone: Countries with a sound fiscal set-up were not supporting any initiatives that might lay the ground for higher inflation or a devaluation of the currency - common measured applied by distressed countries in the past. Yet, prior to the sovereign debt crisis, the peripheral countries - nevertheless - benefited from low interest rates and high supply of capital.

\section{Literature Review}

Our findings relate to research focusing on the impact of sovereign risk on debt-related financial products in general as well as to the wide range of literature determining pricing factors on CDS spreads, with the latter being divided into micro- as well as macro-economic factors.

Based on weekly CDS spread data for European banks, Ejsing and Lemke (2011) investigate to what extent risk was actually transferred from banks to the government during the financial crisis. They show that after the announcement of government rescue packages not only were the CDS spreads of banks decreasing and sovereign CDS spreads increasing, but also was the level of sensitivity with regard to a worsening of the financial crisis increasing for government debt and decreasing for bank debts. This risk transfer from the private to the public sec- 
tor is also documented by Dieckmann and Plank (2012). In addition, their paper shows that the condition of a country's financial system as well as the state of the worldwide financial system is a significant pricing factor for sovereign CDS spreads.

Set against the financial crisis between 2007 and 2010, Alter and Schueler (2012) focus on the relationship between sovereign CDS spreads and banks' CDS spread levels. They show that sovereign CDS spreads are an important pricing factor for bank CDS spreads - in particular prior to a bank bailout - and find that the interdependence between banks and their home country is rather heterogeneous between countries, but homogenous within countries.

Carr and Wu (2007) document a positive correlation between sovereign risk (measured by sovereign CDS spreads) and currency implied return volatilities. They observe that sovereign CDS spreads actually co-vary with both the currency option implied volatilities as well as the slope of the implied volatility curve in moneyness.

Ismailescu and Kazemi (2010) investigate the interaction between sovereign credit rating announcements and sovereign CDS spreads. They show that positive rating events (e.g. upgrades) have a strong and positive impact on CDS markets (e.g. lower spreads), whereas CDS markets actually anticipate negative rating events leading to no impact in case of a downgrade for example (see also Finnerty et al., 2013). In addition, De Bruyckere et al. (2013) focus on contagion between bank risk and sovereign risk. They show that contagion between bank risk and sovereign default risk exists (measured by correlation of CDS spreads) and is more present for banks being dependent on short-term funding and less focused on traditional banking activities. They also empirically prove that the link between bank and sovereign default risk becomes stronger the more debt the bank accumulates from that respective country on its balance sheet. Acharya et al. (2013) confirm the link between bank risk and country risk. They show that post-bailout changes in sovereign CDS have a significant impact on bank CDS levels. Demirgüç-Kunt and Huizinga (2013) show that bank CDS spreads are actually decreasing with stronger public finances. The better the underlying sovereign risk, the lower are the premiums paid for CDS contracts.

Badaoui et al. (2013) aim to gain an understanding of what drives sovereign CDS spreads. Their research reveals that sovereign CDS spreads are driven in large parts by liquidity - in contrast to sovereign bonds - for which liquidity is of a lesser importance. They also explain that the increase in sovereign risk throughout the recent financial crisis was due to liquidity risk and - as expected - due to higher default intensity. 
White and Hull (2000, 2001) were the first to introduce the framework of counterparty risk into the pricing process of CDS contracts. They defined counterparty risk as the default risk of the protection buyer or the protection seller, respectively, and extended their framework (White and Hull, 2001) by also estimating the default correlation between these two parties.

Galil et al. (2014) provide a recent analysis on a wide range of CDS pricing factors. They find that in particular stock return, the change in stock return volatility, the change in the median CDS spread in the rating class, as well as ratings are important pricing determinants. Their research confirms previous studies on pricing factors of CDS contracts (e.g. Blanco et al., 2005; Byström, 2005; Zhang et al., 2008; Skinner and Townend, 2002). Ericsson et al. (2009) provide empirical proof that leverage also counts as an important pricing factor. Furthermore, Fabozzi et al. (2007) show that liquidity matters and document a negative correlation between liquidity and the CDS pricing level, which is also confirmed by Tang and Yan (2007).

Our paper blends into existing literature in two dimensions: First, it introduces sovereign risk to the literature on the pricing of corporate CDS spreads. Second, it adds to the understanding of the risk transfer between private and public debt. In addition to sovereign risk, we will apply a range of the above-mentioned, generally accepted pricing factors as control variables for our regression analysis.

\section{Data Sample}

In our empirical analysis we focus on corporations from the European market stemming from 10 different countries. The Markit iTraxx Europe Index Series 17 comprises 125 CDS contracts on senior unsecured debt with a maturity of 5 years on investment grade entities. This approach helps us to rule out any kind of selection bias or distortions coming from the lack of trading volume or insufficient company size. We cover a time period of three years starting in January 2009. Furthermore, we focus on the underlying CDS contracts' standard maturity of 5 years as this approach is also in accordance with finance literature in the field.

In line with earlier empirical studies working with CDS data, we also use last quoted monthly data for the performed panel analysis to reduce distortions from autocorrelation (Zhang et al., 2008). We excluded all reference entities which were either not publicly listed (because information on equity returns and the respective volatility is needed for our set of control variables) or had CDS spreads quoted for less than 36 months, or missing values. We also exclud- 
ed the reference entities which are headquartered in countries where sovereign CDS quotes were not available for the whole observation period. To complete our data set, we had to combine various sources of data: from Bloomberg trading platform we retrieved the CDS spreads of reference entities and countries, from Thomson Reuters Datastream we extracted equity prices, equity index levels, interest rates, and balance sheet data if publicly available, from the CapitalIQ database we got data to determine the ratio of bank debt over total debt, and finally we had to analyze the individual annual reports of the corporations to obtain the ratio of revenue in home country over total revenue.

Having removed all observations with missing values, our sample of companies sums up to 107 reference entities (see the resulting company list in Appendix I). The table in Appendix II shows the distribution of companies across ten countries and across industries, where the clustering of the latter into five industries is taken from the Markit iTraxx list and contains the following industries: Autos and Industrials, Consumers, Energy, Financial, and Technology Media Telecommunications (TMT).

As the analyzed reference entities origin from different industries as well as different countries and rating classes, we assume that the probability that our results are impacted by a selection bias is fairly small. Rating values are assigned according to Moody's rating classification and if not available, the Standard \& Poor's credit rating is used to determine the rating classes. In total, the iTraxx data sample consists of 3'745 observations.

(insert Table 1 about here)

Table 1 presents an overview of the yearly mean CDS spreads across different rating categories. The expected negative relationship between quality of rating class (e.g. low default probability) and level of CDS spreads is partially confirmed for our data sample, but surprisingly only for 2009 and not for the total sample. We analyzed this effect deeper and found that the effect comes from the years 2010 and 2011 and particularly from the non-distressed countries. Thereby, we detect an already well documented trend of inconsistencies in the CDS spreads with regard to rating due to other influencing factors (among others e.g. Callen et al., 2007, on the impact of earnings on CDS spreads; Hull et al., 2004, on the relationship between rating announcements and CDS spreads). 
Table 2 displays summary statistics of the CDS pricing determinants. We listed the corporate CDS as the dependent variable, the sovereign CDS as the major explanatory variable of interest, and the control variables. The table in Appendix III provides a list of all variables used in the analysis including their respective definitions. The table in Appendix IV shows a correlation matrix which we used to check for multicollinear variables, which is not the case.

(insert Table 2 about here)

\section{Methodology}

In the following, we will explain our measure for sovereign risk as well as the main variables of interest and the standard set of control variables we included in our analysis. The empirical identification strategy is rather straightforward: we apply control variables in line with existing literature to explain CDS spreads and add sovereign risk and some additional control variables to further disentangle the effect of sovereign risk on corporate credit risk. Besides, we also control for company and time fixed effects.

\section{i. Sovereign Risk and Corporate Credit Default Swaps}

To measure the impact of sovereign risk on corporate credit default swap spreads we include the matched maturity sovereign CDS spread (CDS_Country) of the company's home country in our regression analysis. As a first approximation we show the distribution of the respective sovereign CDS spreads over the relevant time period (2009-2011), clustered for distressed and non-distressed countries in Figure 1.

(insert Figure 1 about here)

What can be clearly seen from Figure 1 is, that the CDS spreads for distressed and nondistressed countries start at pretty much the same level and that during the analyzed time period the spreads increase for both groups. It becomes obvious though, that the spreads increase tremendously for the distressed country group. 
Based on the above first intuition, the sovereign CDS spread becomes our major focus of interest: besides the fact that the overall sovereign spread increased and that the levels are different for the two groups, we would expect to see an increasing effect of sovereign risk on corporate spreads over time. We expect to see the increasing impact of sovereign risk on company risk in particular as our data set focuses on the European sovereign crisis, where decreasing sovereign creditworthiness became a major issue for peripheral countries of the Eurozone. At the same time, the credit spreads for core Eurozone countries actually decreased as investors were rushing into more secure government debt driving down the corresponding yields. We will control for this effect in order to be robust with respect to industries and ratings.

In our further analysis we want to disentangle the effect for areas of corporate activity, i.e. we want to understand if the impact of sovereign risk is more pronounced for companies with a strong bias of asset side activities in their home countries. We measure this effect by the percentage of a company's revenues in the respective home country per year (revenue home country ratio, $\mathbf{R H C}$ ). This information was hand-collected from the individual annual reports of the companies in our data sample. Thus, we also capture not only the cross-sectional impact but also the time-series effect observed throughout the sovereign debt crisis in Europe. All calculations are based on historical Euro exchange rates with regard to the markets not denominated in Euro. Our hypothesis is that stronger reliance on local operations might increase the exposure to sovereign risk as local business activity cannot be diversified with international exposure. We assume that, if sovereign risk is increasing, a country's economy turns worse, putting pressure on domestic sales. Therefore, there should be a strong link between local embeddedness of the business and the impact of sovereign risk on corporate creditworthiness.

In line with existing literature (e.g. Alter and Schueler, 2012), we conjecture that a high impact of sovereign risk on corporate risk might stem from the liability side of the balance sheet, as the dependence on local banks with regard to financing need of the corporation might be interpreted as an increased exposure towards the creditworthiness of the sovereign. Higher sovereign risk is associated with higher CDS spreads, which in turn increases the refinancing costs for banks (Acharya et al., 2013; Demirgüç-Kunt and Huizinga, 2013). If local banks have to bear higher refinancing costs, interest rates for corporate loans will also go up. Particularly, when the financial intermediation system in the country follows a typical relationship banking type of business model and the access to international capital markets is not so sub- 
stantial, this effect might kick in. We therefore operationalize this analysis by looking at the percentage of bank lending over total lending (bank debt, $\boldsymbol{B D}$ ). The hypothesis is that a stronger reliance on local bank lending might increase the impact of sovereign risk on corporate risk. Bank debt is defined as the total amount of bank debt outstanding for each reference entity including drawn credit lines and loans and was derived on a quarterly basis from CapitalIQ. Total debt is also based on quarterly figures for the observation period and includes long-term and short-term debt as well as capital leases for each of the reference entities.

\section{ii. Control Variables}

Based on the above mentioned existing literature on the drivers of CDS spreads, we analyzed a large universe of control variables, first on a univariate basis and then - after testing for collinearity - included a selected subset of the original covariates in our multivariate analysis. In the following, both economic reasoning for including a variable as well as operationalization and definition of the proxies are explained. Like other finance papers in the field, we follow Das et al. (2009) and cluster the control variables in market-based, firm-based, or tradespecific determinants.

\section{Market-based Determinants}

Following Benkert (2004) we include the risk-free rate of return as the first market-based determinant in our regression and expect a negative relationship between the risk-free rate of return and the corporate CDS spread. The author argues that decreasing spot rates in recessionary times could be accompanied by higher corporate default rates, which in turn manifests in higher CDS spreads. We include the short-term rate by considering the 2-year Treasury bond yields of the respective country of the underlying corporation (Govt_2Y).

As a second market-based variable we include the slope of the term structure in our analysis even though the empirical prediction of the direction of the impact is not particularly clear: Following Estrella and Mishkin (1996) a higher slope might imply an anticipated improvement of the overall economy, resulting in lower default probabilities and therefore decreasing CDS spreads. In contrast, following Zhang et al. (2008) the higher slope could trigger increasing inflation rates, which might deteriorate the overall macroeconomic conditions and result in higher CDS premia. Despite contradicting hypotheses on the direction of the impact, we include the term structure in our analysis and follow Ericsson et al. (2009). We calculate the Slope at the end of each month in our observation period by subtracting the 10-year risk-free 
interest rate of the respective country from the 2-year risk-free interest rates of the respective country. Based on the difference we then calculated the monthly change of the Slope (rSlope).

Next we include the equity index returns of the respective country (rEQIndex), the overall CDS Index (Index), and the market volatility of the respective equity index (EQIndex_Vola) in our analysis. For each country of our data sample we identified a primary blue chip equity index (e.g. FTSE 100 for UK) and calculated on the basis of end of month values corresponding monthly returns. The overall CDS Index returns (rIndex) are based on the iTraxx Investment Grades and include the most liquid 125 European reference entities. Again, the monthly returns (changes) are calculated in percentages based on end of month figures.

We expect a negative relationship between the equity index and CDS spreads and - in line with Zhang et al. (2008) - a positive impact of market volatility and the CDS index on the respective CDS spreads.

\section{Firm-specific Determinants}

In line with existing literature, we include the corporate rating in our analysis (Daniels and Jensen, 2005). Following Cossin and Hricko (2001) the ratings are either analyzed by introducing dummy variables for each rating class or by assigning numeric values (Rating) to each rating class ranging from 1 for the highest rating (AAA or Aaa) and 17 for the lowest rating class (C), where we use the Moody's long-term issuer credit rating for each corporation and if not available, the Standard \& Poor's credit rating is used.

Besides rating, we include in our analyses the leverage ratio (Leverage) of the corporation as the theory based on structural credit models indicates that the distance to default measured by leverage is a strong indicator for future creditworthiness (Merton, 1974). Following Ericsson et al. (2009) the leverage ratio of the reference firm $i$ in month $t$ is operationalized as follows:

$$
\text { Leverage }_{i t}=\frac{\text { Total Debt }_{i t}+\text { Preferred Equity }_{i t}}{\text { Market Value }\left(\text { Equity }_{i t}+\text { Total Debt }_{i t}+\text { Preferred Equity }_{i t}\right.},
$$

with total debt and preferred equity being book values quoted on an annual basis. The market value of equity equals the market capitalization defined as the factor of the last equity price and the number of shares outstanding at the end of month $t$. Following the indication of structural credit models, we also include firm-specific equity returns (rEQFirm) in our analysis as the positive impact of returns on the equity of the underlying company might reduce the impact of a large leverage on CDS spreads (Zhang et al., 2008). The same argument holds for 
equity volatility (EQFirm_Vola), which is defined as the rolling standard deviation $\sigma_{t}$ over the 24 months prior to time $t$. Equity volatility is a good proxy for asset volatility, which commonly used in pricing models for CDS spreads and seems not to be correlated with other explanatory variables (see also Cossin and Hricko, 2001). Historical market volatility EQIndex_Vola is estimated analogously.

\section{Trade- specific Determinants}

Tang and Yan (2006) document a pattern for CDS markets where higher liquidity has a negative impact on CDS spreads, which is the reason for us to include liquidity as an explanatory variable of corporate CDS spreads. Badaoui (2013) also reports the importance of liquidity risk on the risk premia of sovereign CDS, but this impact is already incorporated in the Sovereign CDS Spreads as our major variable of interest. We therefore only use relative bid-ask spreads divided by the last price quote of the traded instruments in order to obtain a proxy for the liquidity (CDS_Liq) of the corporate CDS spreads from a transaction costs perspective. The last monthly bid and ask quotes are derived for each CDS contract.

\section{Empirical Results}

\section{i) Baseline Regressions}

Before we explain the results of panel regression analysis, we describe shortly a set of tests on the underlying data set. We started with the Lagrangian multiplier test for serial correlation of errors (Wooldridge, 2002) and continued with excluding multi-collinearity of the considered variables. With regard to the first step, we followed an established approach in the CDS literature as, we first applied the first differences approach (absolute change during one month) to cope with serial autocorrelation, but only the return approach (relative change during one month) solved the problem indicated with the prefix ' $r$ ' preceding each variable in our regression model.

With regard to multi-collinearity, we had to remove the following variables from our multivariate analysis: CDS Index (Index), volatility of the equity index of the respective country (EQIndex_Vola), and rating (Rating). We perform some robustness tests for rating though. 
After controlling for serial autocorrelation and multi-collinearity, we specify a fixed-effect model based on a Hausman test and control for entity- as well as time-fixed effects. Moreover, we also employ a heteroskedasticity-robust variance matrix. ${ }^{1}$

Considering the above discussed adjustments, the general regression model can be described as follows:

$$
\begin{aligned}
& r C D S_{-} \text {Spread }_{i t}=c+\beta_{1} r C D S_{-} \text {Country }_{i t}+\beta_{2} r C D S_{-} \text {Liq }_{i t}+\beta_{3} r E Q F i r m_{i t}+
\end{aligned}
$$

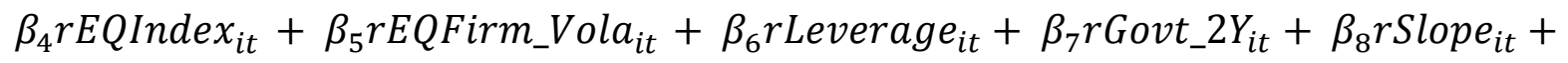

$$
\begin{aligned}
& a_{i}+a_{t}+e_{i t}
\end{aligned}
$$

with $a_{\mathrm{i}}$ und $a_{t}$ representing entity- and time-fixed effects.

If our hypotheses can be confirmed, we would expect that sovereign risk and the corresponding measure rCDS_Country have a significant and economically relevant impact on CDS spreads with an increase over time and a pronunciation towards countries which were more severely hit by sovereign crisis than others. The multiple regressions results of Table 3 all rely on time- and entity-fixed effects.

The results in Table 3 indicate that sovereign CDS spreads are indeed significantly linked $(+0.104 * * *)$ to the underlying corporate CDS spreads (Column 1) and the explanatory power (R-squared) can be slightly increased by including our sovereign risk measure in the base line regression (Column 1 vs Column 2). The control measures show the expected directions even though it is worth mentioning that for the total sample displayed in Column 1, the leverage measure shows insignificant results.

We further see that the impact of sovereign credit risk is actually increasing with aggravation of the sovereign crisis in 2010 (Column (3) covering the time span from January 2009 until April 2010 vs Column (4) covering the time span between May 2010 until December 2011). The coefficient for the impact of sovereign risk on corporate debt more than doubled when compared to the earlier sample $(0.128 * * *$ vs $0.0519 *)$, which is a strong indicator for the impact of increased influence of sovereign risk on corporate risk. At the same time, the explana-

\footnotetext{
${ }^{1}$ In order to test for heteroscedasticity, a modified Wald test for groupewise heteroscedasticity is performed whereby the null hypothesis of equal group variances is rejected on high significance levels. In order to control for this effect, a heteroscedasticity-robust error variance matrix is employed (see e.g. White, 1980).
} 
tory power for this model (Column 4) is significantly higher compared to the base line regression run on the total sample.

(insert Table 3 about here)

Besides an overall statistically significant impact of sovereign CDS spreads and an increase of this impact over time, we also observe that the link is actually stronger for distressed countries, which experienced massive refinancing problems followed by exorbitantly highly interest rate levels (Column (5) vs Column (6)), namely Spain and Italy. Out of our group of ten Eurozone companies, Spain and Italy were the one most significantly hit by the sovereign debt crisis. However, they were not bailed out by the International Monetary Fund and other European countries like for example Greece. Both countries experienced significant refinancing problems and in the case of Spain, the European central bank was forced to provide a financing for the local banking sector. The documented result does not come as a surprise, but the size of the impact $\left(0.276^{*}\right.$ vs $\left.0.104 * * *\right)$ is remarkable. These latter results, however, have to be interpreted with care as the observations in the distressed countries (13 companies) are fewer than in the non-distressed country sample (94 companies). Therefore, we performed an additional (unreported) analysis not on a digital distressed flag, but by using the median sovereign CDS spread during the sample period. We divided the countries in two groups with the median as the cut-off point. Thereby we increase the number of countries in the group of countries with refinancing problems with some interesting results: the effect is robust even for this broader definition of distress. The coefficients for distressed countries above the median sovereign spread becomes $0.186^{* * *}$ as compared to $0.276^{* * *}$ for the digital definition of distress, and for the non-distressed countries the coefficients are $0.0492^{* *}$ as compared to $0.0933^{* * *}$ in the narrow definition sample.

\section{ii) Robustness}

As we had to remove the variable rating from our analysis because it dropped off in the multivariate regression, we performed the underlying base line regression for subsamples of rating categories since we want to know if the effect is stable across ratings. 
(insert Table 4 about here)

As can be seen from Table 4, the effect of sovereign risk on corporate risk for the full sample is very pronounced for the rating category covering ratings from A1-A3, which indicate intermediate credit quality $\left(0.119^{* * *}\right)$. For the worst rating categories (Baa1-Ba1), the effect is significant, but smaller than for the medium ratings $(0.0999 * * *)$. We do not find a significant effect for the highest rating categories. We interpret these results in the direction that the impact of sovereign risk is rather robust across rating categories but it is particularly pronounced in the medium and lower ratings categories. The better ratings do not show a significant result, which might be interpreted in the sense that in this category the sovereign risk does not have an impact on the corporate risk. Since ratings are quite often correlated with company size (e.g. the average size of AAA-rated companies is higher than the size of a BBB-rated company), we conducted unreported robustness checks for size (measured by total assets). We can conclude from a sample spilt analysis (median as cut-off) that the results for the impact of sovereign risk on corporate risk is robust for corporations of different size $(0.102 * * *$ for small companies versus $0.0964^{* *}$ for large companies). We also tried the inclusion of size in the baseline regressions but without any impact on the observed levels of significance. We therefore consider our results to be robust against size effects in the underlying sample. Given that our empirical analysis focuses on the most liquid CDS spreads written on the biggest European counterparties (e.g. our sample is based on the iTraxx constituents) the dispersion with regard to size is biased in our data sample towards big corporations.

As a second robustness test we performed our above base line regression again on a sample excluding banks. The economic reasoning for this is based on a potential endogeneity issue, which might stem from a reverse causality caused by banks: if part of the sample consists of systemically important banks (especially in stressed countries), the health of the banking sector might impact sovereign risk. We can confirm that our results in the baseline regressions are robust against reverse causality (the coefficient for the impact of sovereign risk becomes $0.0901^{* * *}$ compared to $0.104 * * *$ in column 1 of Table 3 ) and the results are also robust for the sample split with regard to years $(0.0561 *$ for the non-bank sample versus $0.0519 *$ for the total sample for Jan 2009 - Apr 2010, and 0.104*** for the non-bank sample versus $0.128 * * *$ for the total sample for May 2010 - Dec 2011. For the distressed countries, however, we cannot confirm the impact of sovereign risk on corporate risk after we excluded banks from the 
sample; here the effect seems to be strongly driven by the financial industry, which is impacted strongly and significantly by the respective sovereign risk.

Finally, the results are robust and comparable with regard to the above mentioned rating analysis for both the total and the non-bank sample.

\section{iii) Does a (local) home market bias drive the results?}

In a second step, we try to understand the reasoning behind the documented impact of sovereign risk on the pricing of the underlying corporate CDS spreads. For most companies the domestic market (where the company HQ is located) is the key market with typically the most operational activity taking place. Thus, we argue that the negative impact of sovereign risk on the corporate credit risk level is justified. Therefore, a negative outlook for the domestic economy is ultimately linked to decreasing sales, which in turn will trigger a lower level of profitability and a lower creditworthiness of local corporations. Accordingly, we hypothesize that a strong home country bias of revenues leads to a higher dependency of corporate creditworthiness on sovereign risk.

(insert Table 5 about here)

As can be seen in Table 5, we addressed this issue by analyzing two different groups of sub samples: in Column 1 we analyzed a subsample of companies where less than $29 \%$ of the annual revenue, which corresponds about to the median of the total sample, stems from the home country of the company (defined by location of the headquarter). Column 2 on the other hand shows the companies with more than $29 \%$ of revenues (earned) in the home country (revenue home country, RHC). We find that the coefficient for sovereign risk increases to $0.139 * * *$ for the companies with a strong home country bias in revenues as opposed to a coefficient of $0.068^{* * *}$ for the other sample. We conjecture from these results, that the strong reliance of the revenues on the home country indeed increases the impact of sovereign risk on corporate risk. The result itself is not surprising; however, the mere size of the effect - almost double the effect for companies with a stronger national exposure in terms of revenues - is quite remarkable. 
Second, we also control for the refinancing activities of companies, which may also be impacted by the conditions of the corresponding sovereign risk. During the European sovereign debt crisis banks in distressed countries experienced difficulties to refinance themselves. This shortage of capital supply drove up banks refinancing costs. Under the assumption that borrowing from banks is predominately a domestic business, we could argue that a higher dependency on (local) bank debt should also lead to a higher impact of the sovereign counterparty risk on corporate CDS spreads.

Accordingly, we analyzed the refinancing side of the companies and the ratio of bank debt over total debt to get an approximation of the dependence on the local / national lending market with regard to corporate refinancing. As can be seen in Table 5, we again split the sample in companies with equal or less than $8.57 \%$ bank debt over total debt with the cut-off being the median of the overall sample (Column 3). It is worth noting, that the median is rather low for a sample of European firms where we would have expected a stronger reliance on banking relationships. However, access to international capital markets seems to be given and comparable to companies from other jurisdictions (e.g. from the United States).

Column 4 displays the companies with higher bank debt to total debt ratios, i.e. higher than the median. As can be seen from the analysis, the coefficients of the two samples for the impact of sovereign risk are slightly different $\left(0.121^{* * *}\right.$ vs $\left.0.097^{* * *}\right)$, but due to large standard errors the resulting difference is not significant. Therefore, we interpret our results as follows: the dependence of corporate activity on national markets has a strong influence on the exposure of the corporation towards sovereign risk. This effect is, however, not confirmed for the refinancing side of the company’s balance sheet. ${ }^{2}$

Our interpretation is further confirmed by unreported regression analyses we performed to better understand the impact of revenue in the home country (RHC) and bank debt (BD). Therefore, we included the interaction terms RHC*rCDS_Country and BD*rCDS_Country in the analysis along with introducing BD and RHC as additional explanatory variable. From these tests our preliminary results from the sample splits can be confirmed: The relationship between bank debt and the impact of sovereign risk is not given, i.e. the interaction term is neither statistically significant nor economically relevant. The analysis for the home country bias, however, shows a positive and significant value for the interaction term $\left(0.093^{*}\right)$, which

\footnotetext{
${ }^{2}$ This interpretation, however, needs to be handled with care as per definition the sample suffers from a sample bias towards large corporations. The observed link between sovereign risk and corporate credit risk with regard to bank debt might likely be even stronger for SMEs that rely more heavily on bank financing like also other authors confirm (Bendendo and Collar, 2013).
} 
supports the result that the exposure towards sovereign risk is more severe and heavily influenced by the percentage of operational activity of the company in its home country.

In an unreported a subsample analysis, we again controlled for the impact of the banking sector. The results relying on a sub-sample excluding banks are fairly robust for the subsample without banks: The impact of revenue in home country is a little less pronounced but still solid and significant for the non-banking sample $\left(0.0660^{* *}\right.$ versus $0.0999 * * *$ compared to $0.0676^{* * *}$ versus $0.139 * * *$ in the total sample). The same holds for the impact of bank debt with comparable results between the overall and the non-bank sample.

\section{Conclusion}

Against the background of the recent sovereign debt crisis in Europe, we show that for CDS markets, sovereign risk overleaps to the pricing of corporate debt instruments. We extend existing literature and find that this effect is not only present for banks but also for corporates from other industries. We document that the impact of sovereign CDS is the highest in case of the so-called peripheral Eurozone countries and also increased for the whole data sample with an intensifying sovereign debt crisis in 2010/11. We are the first to explain this effect by a strong dependence to the local market of a country in which a corporation is headquartered: The impact of sovereign risk increases with a home bias to the local market (e.g. high domestic sales ratio). However, we do not find significant empirical proof that the link between sovereign risk and corporate credit risk is driven by access to local bank financing. 


\section{References}

Acharya, V., Drechsler, I., and Schnabl, P. (2013). Pyrrhic Victory? Bank Bailouts and Sovereign Credit Risk. Working Paper, NYU-Stern.

Alter, A. and Schueler, Y. (2012). Credit spread interdependencies of European states and banks during the financial crisis. Journal of Banking and Finance, 36, pp. 3444-3468.

Badaoui, S., Cathcart, L., and El-Jahel, L. (2013). Do sovereign credit default swaps represent a clean measure of sovereign default risk? A factor model approach. Journal of Banking and Finance, 37, pp. 2392-2407.

Bedendo, Mascia and Colla, Paolo (2013). Sovereign and Corporate Credit Risk: Evidence from the Eurozone (June 1, 2013). Available at SSRN: http://ssrn.com/abstract=2212089 or http://dx.doi.org/10.2139/ssrn.2212089

Benkert, C. (2004). Explaining credit default swap premia. Journal of Futures Markets, 24 (1), pp. 71-92.

Blanco, R., Brennan, S., and Marsh, I. (2005). An empirical analysis of the dynamic relationship between investment-grade bonds and credit default swaps. Journal of Finance, 60, pp. 2255-2281.

Byström, H. (2005). Credit default swaps and equity prices: the iTraxx CDS index market. Working Paper, Lund University.

Callen, J., Livnat, J., and Segal, D. (2009). The Impact of Earnings on the Pricing of Credit Default Swaps. The Accounting Review. 84 (5), pp. 1363-1394.

Carr, P. and Wu, L. (2007). Theory and evidence on the dynamic interactions between sovereign credit default swaps and currency options. Journal of Banking and Finance, 31, pp. 2383-2403.

Cossin, D., and Hricko, T. (2001). Exploring for the determinants of credit risk in credit default swap transaction data. Working Paper, HEC University of Lausanne.

Daniels, K.N., and Jensen, M.S. (2005). The effect of credit ratings on credit default swap spreads and credit spreads. Journal of Fixed Income, 15 (3), pp. 16-33.

Das, S.R., Hanouna, P., and Sarin, A. (2009). Accounting-based versus market-based crosssectional models of CDS spreads. Journal of Banking and Finance, 33, pp. 719-730.

De Bruyckere, V., Gerhardt, M., Schepens, G., and Vennet, R. (2013). Bank/sovereign risk spillovers in the European debt crisis. Journal of Banking and Finance, 37, pp. 47934809. 
De Santis, R. (2012). The euro area sovereign debt crisis - safe haven, credit rating agencies and the spread of fever from Greece, Portugal and Ireland. ECB working paper, no 1419, February 2012.

Demirgüç-Kunt, A. and Huizinga, H. (2013). Are banks too big to fail or too big to save? International evidence from equity prices and CDS spreads. Journal of Banking and Finance, 37, pp. 875-894.

Dieckmann, S. and Plank, T. (2012). Default Risk of Advanced Economies: An Empirical Analysis of Credit Default Swaps during the Financial Crisis. Review of Finance, 16, pp. 903-934.

Ejsing, J. and Lemke, W. (2011). The Janus-headed salvation: Sovereign and bank credit risk premia during 2008-2009. Economic Letters, 110, pp. 28-31.

Ericsson, J., Jacobs, K., and Oviedo, R. (2009). The determinants of credit default swap premia. Journal of Financial and Quantitative Analysis, 44 (1), pp. 109-132.

Estrella, A. and Mishkin, F.S. (1996). The yield curve as a predictor of US recessions. Current Issues in Economic and Finance, 2 (7), pp. 1-6.

Fabozzi, F.J., Cheng, X., and Chen, R.-R. (2007). Exploring the components of credit risk in credit default swap. Finance Research Letters, 4, pp. 10-18.

Finnerty, D., Miller, C., and Chen, R. (2013). The impact of credit rating announcements on credit default swap spreads. Journal of Banking and Finance, 37 (X), pp. 2011-2030.

Galil, K., Shapir, O., Amiram, A., and Ben-Zion, U. (2014). The determinants of CDS spreads. Journal of Banking and Finance, 41, pp. 271-282.

Hui,C. and Chung, T. (2011). Crash risk of the Euro in the sovereign debt crisis of 2009-2010. Journal of Banking and Finance, 35, pp. 2945-2955.

Hull, J. and White, A. (2000). Valuing credit default swaps I: No counterparty default risk. Journal of Derivatives, 8 (1), pp. 29-40.

Hull, J. and White, A. (2001).Valuing credit default swaps II: Modeling default correlations. Journal of Derivatives, 8 (3), pp. 12-22.

Hull, J., Predescu, M. and White, A. (2004). The relationship between credit default swap spreads, bond yields, and credit rating announcements. Journal of Banking and Finance, 28 (11), pp. 2789-2811.

IMF (2012). Global Financial Stability Report - Restoring Confidence and Progressing on Reforms. International Monetary Fund, Washington D.C., USA. 
Ismailescu, I. and Kazemi, H. (2010). The reaction of emerging market credit default swap spreads to sovereign credit rating changes. Journal of Banking and Finance, 34, pp. 2861-2873.

Lane, P. (2012). The European sovereign debt crisis. Journal of Economic Perspectives, 26, pp. 49-68.

Merton, R.C. (1974). On the pricing of corporate debt: the risk structure of interest rates. Journal of Finance, 29 (2), pp. 449-470.

Morkoetter, S., Pleus, J., and Westerfeld, S. (2012). Do CDS Spreads reflect Counterparty Risk? - An Empirical Analysis on the efficiency of CDS pricing. Journal of Credit Risk, pp. 63-88.

Skinner, F.S. and Townend, T. G. (2002). An empirical analysis of credit default swaps. International Review of Financial Analysis, 11, pp. 297-309.

Tang, D.Y. and Yan, H. (2007). Liquidity and credit default swap spreads. Working Paper, University of Hong Kong.

Wooldridge, J.M. (2002). Econometric Analysis of Cross Section and Panel Data. MIT Press, Cambridge, MA.

Zhang, B.Y., Zhou, H., and Zhu, H. (2008). Explaining credit default swap spreads with equity volatility and jump risks of individual firms. Working Paper 181, Bank for International Settlements. 
Figure 1: Development of CDS Spreads in Distressed and Non-Distressed Countries

Monthly average spread (in bps) of the sovereign countries (Source: Bloomberg, 2014).

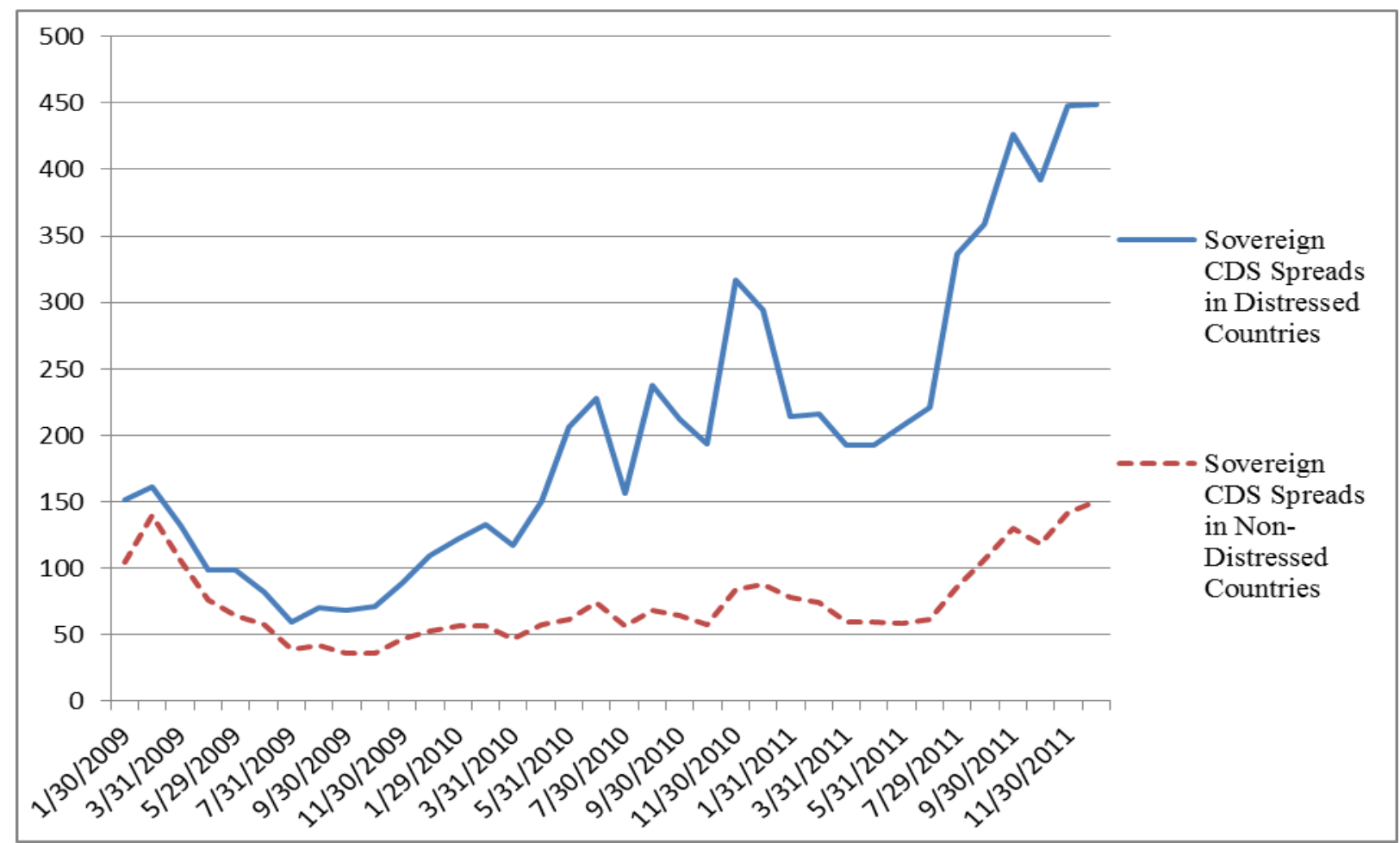


Table 1: Overview of Mean CDS spreads across Rating Categories

Average CDS spreads of the respective index constituents for the three rating clusters ranging from Aaa to Aa3, A1 to A3, and Baa1 to Ba1 ratings

\begin{tabular}{cccc}
\hline & & & \\
& Aaa to Aa3 & A1 to A3 & Baa1-Ba1 \\
\hline Year 2009 - 2011 & 128.79 & 104.27 & 131.89 \\
Year 2009 & & & \\
Year 2010 & 99.26 & 108.73 & 155.2 \\
Year 2011 & 112.62 & 88.48 & 110.46 \\
& 174.47 & 115.88 & 130.16 \\
Non-Distressed Country & 115.33 & & 128.21 \\
Distressed Country & 165.31 & 97.62 & 183.65 \\
& & 176.76 & \\
Non-Financial & 70.12 & & 131.89 \\
Financials & 142.75 & 98.05 & n.a.
\end{tabular}


Table 2: Summary Statistics

\begin{tabular}{cccccc}
\hline Variable & Mean & Std. Dev. & Min & Max & Obs \\
\hline rCDS_Spread & 0.0168 & 0.1810 & -0.4917 & 0.9636 & 3.745 \\
rCDS_Country & 0.0350 & 0.2249 & -0.3883 & 1.0678 & 3.745 \\
rCDS_Liq & 0.0437 & 0.4696 & -17.1532 & 7.6550 & 3.745 \\
rEQFirm & 0.0064 & 0.0989 & -0.5547 & 0.9020 & 3.745 \\
rEQIndex & 0.0049 & 0.0553 & -0.1639 & 0.1888 & 3.852 \\
rEQFirm_Vola & -0.0032 & 0.0628 & -0.5213 & 0.7994 & 3.745 \\
rLeverage & -0.0023 & 0.0599 & -0.4349 & 0.9318 & 3.745 \\
rGovt_2Y & -0.0028 & 0.2502 & -0.7606 & 1.4286 & 3.745 \\
rSlope & 0.0161 & 0.4616 & -0.8591 & 10.2675 & 3.745 \\
\hline
\end{tabular}




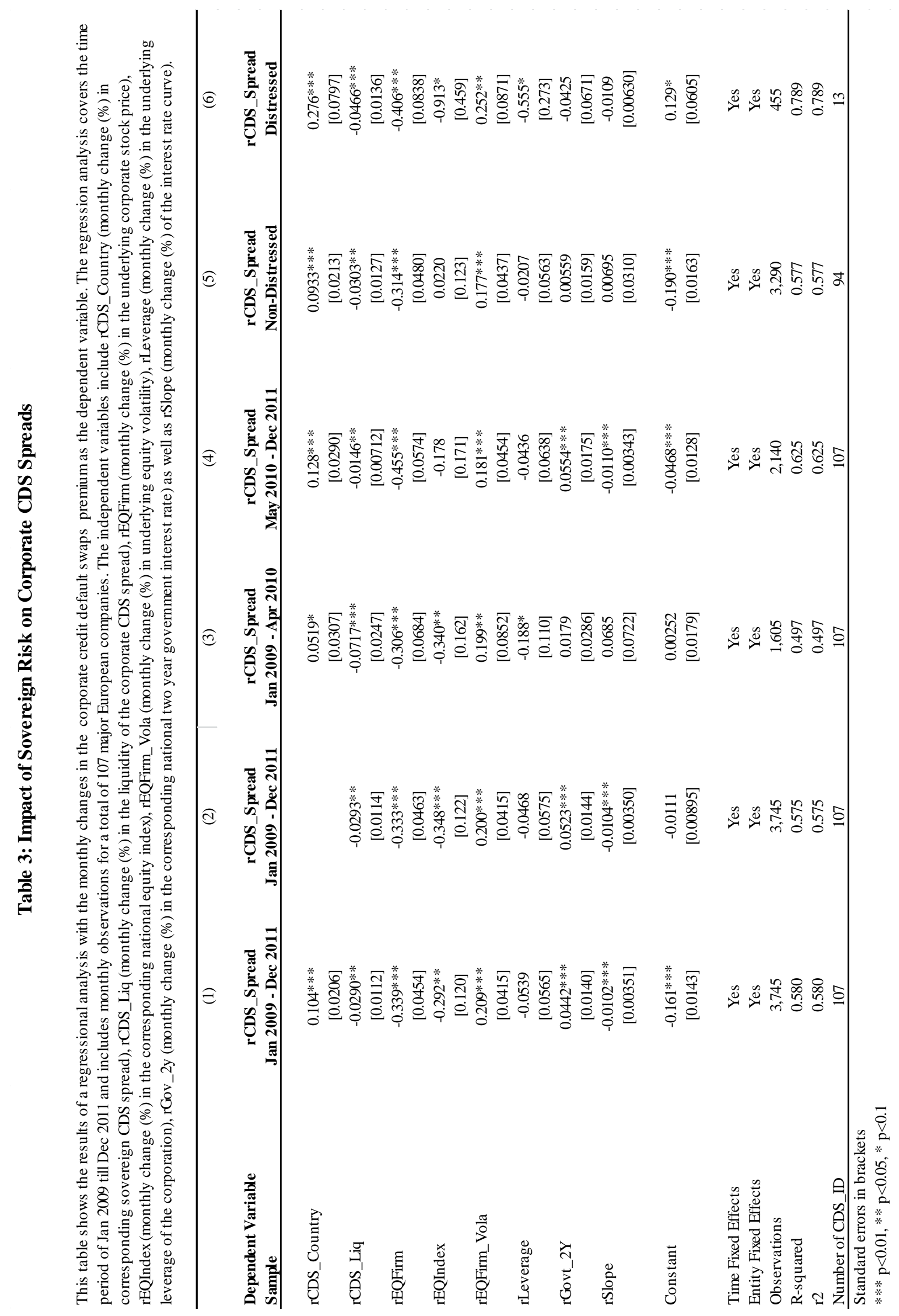




\section{Table 4: Ratings}

This table shows the results of a regressional analysis with the monthly changes in the corporate credit default swaps premium as the dependent variable. The regression analysis is clustered into three rating clusters ranging from Aaa to Aa3, A1 to A3, and Baa1 to Ba1 ratings.

\begin{tabular}{|c|c|c|c|c|}
\hline \multirow{4}{*}{$\begin{array}{l}\text { Dependent Variable } \\
\text { Sample }\end{array}$} & \multirow{2}{*}{\multicolumn{3}{|c|}{$\begin{array}{l}\text { (2) } \\
\text { Sample Split for Rating Categories }\end{array}$}} & \multirow{4}{*}{$\begin{array}{c}(4) \\
\text { Total Sample } \\
\text { rCDS_Spread } \\
\text { Total Sample } \\
\end{array}$} \\
\hline & & & & \\
\hline & rCDS_Spread & rCDS_Spread & rCDS_Spread & \\
\hline & Ааa-Аа3 & A1-A3 & Baa1-Ba1 & \\
\hline \multirow[t]{2}{*}{ rCDS_Country } & 0.0774 & $0.119 * * *$ & $0.0999 * * *$ & $0.104 * * *$ \\
\hline & [0.0510] & {$[0.0386]$} & {$[0.0247]$} & {$[0.0206]$} \\
\hline \multirow[t]{2}{*}{ rCDS_Liq } & -0.0109 & $-0.0521 * * *$ & $-0.0428 * * *$ & $-0.0290 * *$ \\
\hline & {$[0.00666]$} & [0.0114] & {$[0.00952]$} & [0.0112] \\
\hline \multirow[t]{2}{*}{ rEQFirm } & $-0.235 * * *$ & $-0.212 *$ & $-0.334 * * *$ & $-0.339 * * *$ \\
\hline & [0.0634] & {$[0.112]$} & {$[0.0530]$} & {$[0.0454]$} \\
\hline \multirow[t]{2}{*}{ rEQIndex } & 0.0295 & $-0.441^{*}$ & -0.224 & $-0.292 * *$ \\
\hline & [0.179] & [0.228] & [0.207] & {$[0.120]$} \\
\hline \multirow[t]{2}{*}{ rEQFirm_Vola } & $0.121 *$ & $0.185^{* * *}$ & $0.166 * * *$ & $0.209 * * *$ \\
\hline & {$[0.0665]$} & [0.0637] & {$[0.0604]$} & {$[0.0415]$} \\
\hline \multirow[t]{2}{*}{ rLeverage } & -0.125 & -0.00721 & -0.0129 & -0.0539 \\
\hline & [0.229] & {$[0.143]$} & {$[0.0552]$} & {$[0.0565]$} \\
\hline \multirow[t]{2}{*}{ rGovt_2Y } & $0.0694 * * *$ & 0.0442 & $0.0430 * *$ & $0.0442 * * *$ \\
\hline & {$[0.0204]$} & [0.0317] & [0.0183] & {$[0.0140]$} \\
\hline \multirow[t]{2}{*}{ rSlope } & $-0.00504^{* *}$ & 0.00489 & $-0.00703^{*}$ & $-0.0102 * * *$ \\
\hline & {$[0.00235]$} & {$[0.00330]$} & {$[0.00392]$} & {$[0.00351]$} \\
\hline \multirow[t]{2}{*}{ Constant } & $-0.239 * * *$ & $0.160 * * *$ & $-0.155^{* * *}$ & $-0.161 * * *$ \\
\hline & {$[0.0232]$} & [0.0363] & {$[0.0221]$} & {$[0.0143]$} \\
\hline Time Fixed Effects & Yes & Yes & Yes & Yes \\
\hline Entity Fixed Effects & Yes & Yes & Yes & Yes \\
\hline Observations & 910 & 1,156 & 1,679 & 3,745 \\
\hline R-squared & 0.714 & 0.566 & 0.620 & 0.580 \\
\hline Number of CDS_ID & 26 & 34 & 48 & 107 \\
\hline
\end{tabular}

Standard errors in brackets

$* * * \mathrm{p}<0.01, * * \mathrm{p}<0.05, * \mathrm{p}<0.1$ 


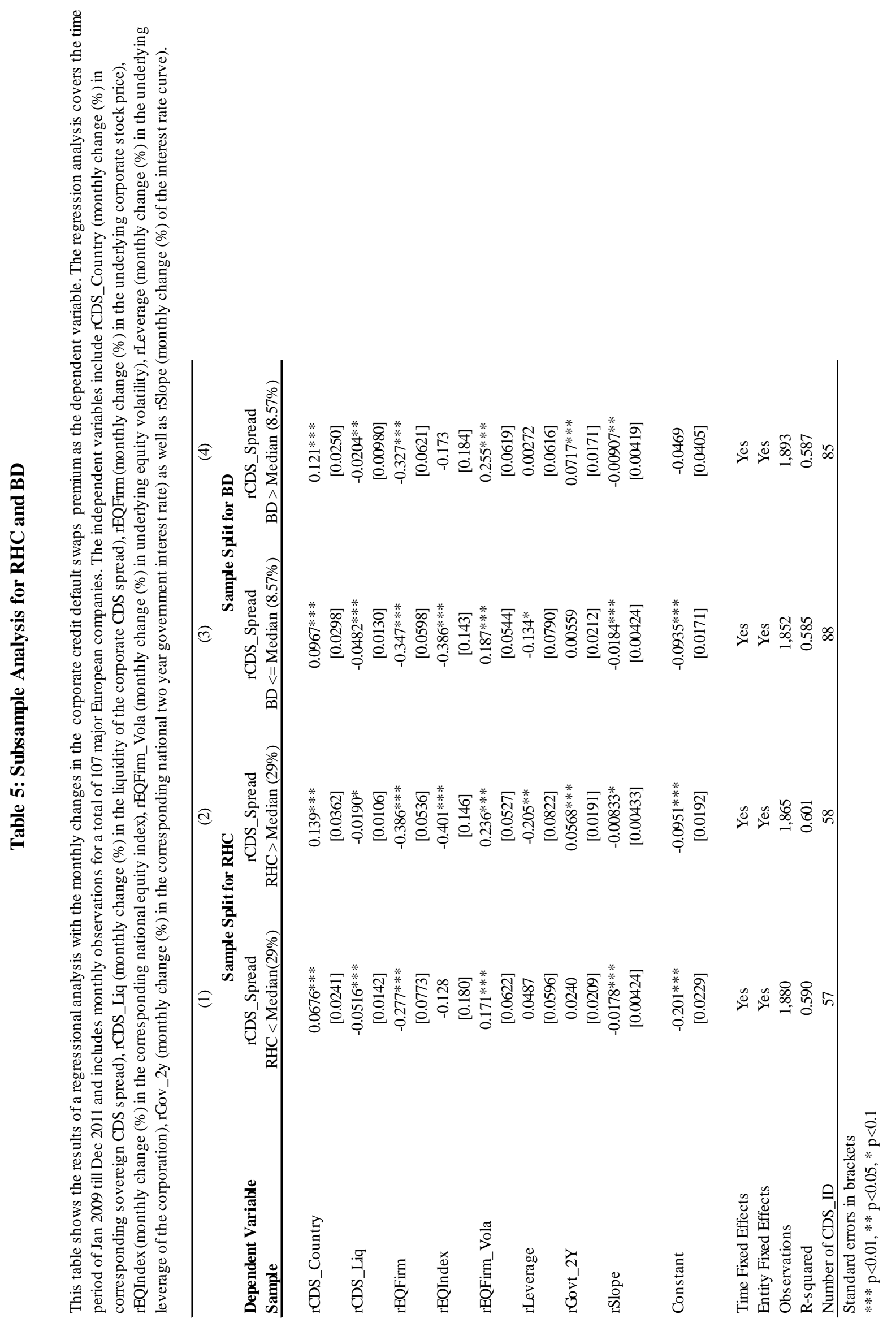




\section{Appendix I: Reference Entities}

Markit iTraxx Europe Index Series 17 Final Member List comprises 125 CDS contracts on senior unsecured debt with maturity of 5 years on investment grade entities. The Markit index rolls every 6 months. In our analysis, we used the following 107 entities.

\begin{tabular}{|c|c|}
\hline \multicolumn{2}{|c|}{ Selection of iTraxx Europe Index Series 17 companies } \\
\hline Adecco & KPN Kon. \\
\hline Aegon & Kingfisher PLC \\
\hline Ahold Koninkljike & LVMH \\
\hline Akzo Nobel NV & Lanxess \\
\hline Allianz & Linde AG \\
\hline Alstom SA & Lloyds Banking Group \\
\hline Anglo American PLC & Marks \& Spencer \\
\hline Assicurazioni Generali & Metro AG \\
\hline Aviva & Michelin \\
\hline Axa & Muenchner Rueck \\
\hline BAE Systems PLC & Nestle SA \\
\hline BASF & Next PLC \\
\hline BMW AG & PPR \\
\hline BNP Paribas & Pearson \\
\hline BT Group & Philips Electronics Kon. \\
\hline Banca Monte di Paschi di Sie & PostNL NV \\
\hline Banco Bilbao Vizcaya Argentaria & Publicis Groupe \\
\hline Banco Santander & RWE \\
\hline Barclays & Rentokil Initial PLC \\
\hline Bayer AG & Repsol \\
\hline Bouygues SA & Royal Bank of Scotland \\
\hline British American Tobacco PLC & SABMiller PLC \\
\hline British Sky & STMicroelectron. \\
\hline Carrefour SA & Sanofi \\
\hline Casino Guichard & Siemens AG \\
\hline Centrica & Societe Generale \\
\hline Cie de St-Gobain & Solvay SA \\
\hline Commerzbank & Suedzucker AG \\
\hline Credit Agricole & Svenska Cellulosa AG \\
\hline Credit Suisse & Swiss Re \\
\hline DSM Koninklijke & Tate \& Lyle \\
\hline Daimler AG & Telecom Italia \\
\hline Danone SA & Telefonica \\
\hline Diageo PLC & Telekom Austria \\
\hline Dt. Bank & TeliaSonera \\
\hline Dt. Telekom & Tesco \\
\hline E.On & Total \\
\hline EADS & UBS \\
\hline EDF & UniCredit \\
\hline Electrolux AB & Unilever \\
\hline EnBW & United Utilities \\
\hline Enel & Valeo SA \\
\hline Eni & Veolia \\
\hline Ericsson & Vinci SA \\
\hline Experian PLC & Vivendi \\
\hline France Telecom & Vodafone \\
\hline GDF Suez & Volkswagen AG \\
\hline Gas tural SDG & Volvo AB \\
\hline HSBC & WPP \\
\hline Hannover Rueck & Wolters Kluwer \\
\hline Henkel AG & Xstrata PLC \\
\hline Holcim Ltd & Zurich \\
\hline Iberdrola & \\
\hline Imperial Tobacco Group & \\
\hline Intesa Sanpaolo & \\
\hline
\end{tabular}




\section{Appendix II: Diversification across industries/countries}

Number of reference entities used clustered per iTraxx industry segment (autos \& industrials, consumers, energy, financials, tmt [technology, media, telecommunications]) and per country of origin (Austria, Belgium, France, Germany, Italy, Netherlands, Spain, Sweden, Switzerland, and UK).

\begin{tabular}{cc||cc}
\hline Industries & iTraxx & Country & iTraxx \\
\hline Autos \& Industrials & 27 & Austria & 1 \\
Consumers & 24 & Belgium & 1 \\
Energy & 14 & France & 24 \\
Financials & 25 & Germany & 20 \\
TMT & 17 & Italy & 7 \\
& & Netherlands & 9 \\
& & Spain & 6 \\
& Sweden & 5 \\
& & Switzerland & 8 \\
& & UK & 26 \\
\hline
\end{tabular}




\section{Appendix III: Definition of Variables}

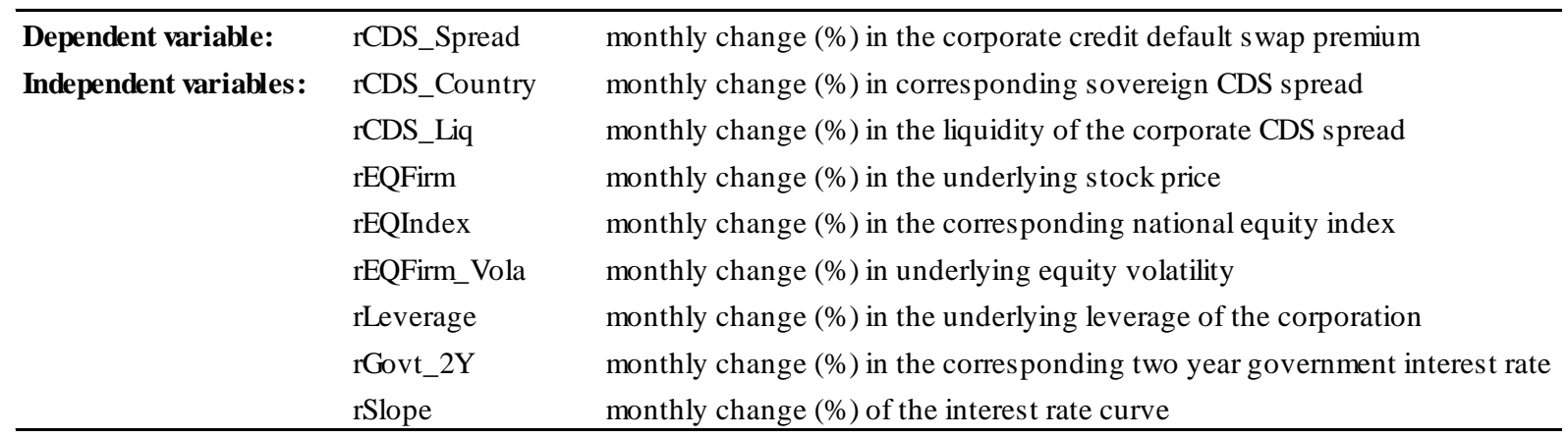


Appendix IV: Correlation Matrix

\begin{tabular}{|c|c|c|c|c|c|c|c|c|c|}
\hline & rCDS & $\begin{array}{r}\text { rCDS } \\
\text { Country } \\
\end{array}$ & $\begin{array}{l}\text { rCDS } \\
\text { _Liq }\end{array}$ & $\begin{array}{l}\text { EQFirm } \\
\text { _Return }\end{array}$ & $\begin{array}{l}\text { EQIndex } \\
\text { _Return }\end{array}$ & $\begin{array}{r}\text { rEQFirm } \\
\text { _Vola } \\
\end{array}$ & rLeverage & rGovt_2Y & rSlope \\
\hline rCDS & 1 & & & & & & & & \\
\hline rCDS_Country & 0.4676 & 1 & & & & & & & \\
\hline rCDS_Liq & -0.1079 & 0.003 & 1 & & & & & & \\
\hline EQFirm_Return & -0.4744 & -0.3822 & 0.0155 & 1 & & & & & \\
\hline EQIndex_Return & -0.5891 & -0.5709 & 0.0193 & 0.6252 & 1 & & & & \\
\hline rEQFirm_Vola & -0.011 & -0.0959 & 0.0004 & 0.1931 & 0.0643 & 1 & & & \\
\hline rLeverage & 0.3376 & 0.2675 & -0.003 & -0.6496 & -0.4604 & -0.0224 & 1 & & \\
\hline rGovt_2Y & -0.1482 & -0.13 & 0.0194 & 0.1112 & 0.1526 & -0.0872 & -0.0954 & 1 & \\
\hline rSlope & -0.0711 & -0.0151 & 0.0003 & 0.0264 & 0.0468 & 0.0134 & -0.1756 & -0.1495 & 1 \\
\hline
\end{tabular}

